\title{
Vietnamese Undergraduates' Attitudes Towards the Use of Facebook for English Language Teaching and Learning
}

\author{
Phan Thi Kim Thao \\ Faculty of Foreign Languages, Van Lang University, Ho Chi Minh City, Vietnam \\ Corresponding author: Email: thaokim.pt@gmail.com
}

\begin{abstract}
Thanks to the presence of ICT, proliferation in social media users has occurred and changed the way human beings socialize with each other worldwide. It is undeniable that the prevalence of Facebook as a dominant platform has put questions about how and why diverse virtual communities have employed it. In relation to academic purposes, Facebook has been considered a supporting tool in many parts of the world. To gain some better insight into the use of Facebook in English language teaching and learning in Vietnam, this study was conducted to investigate students' attitudes towards using Facebook in ELT among English- major students. The sample was 323 Vietnamese respondents. The quantitative method was applied for data analysis. Overall, the result revealed that English-major students in Vietnam expressed positive attitudes towards leveraging the Facebook platform in ELT. Consequently, there was a necessity of ultilizing Facebook as an integral attribute of education in the digital era. To end, some suggestions and implications were raised for ELT development.
\end{abstract}

Keywords: Vietnamese students, ICT, SNS, Facebook Attitudes.

\section{INTRODUCTION}

The advancement of Web 2.0 has provided various noticeable benefits to humanity in many sectors. According to [1] Sánchez, Cortijo, and Javed (2014), technology-based education seems to be crucial in the academic realm. In the field of education, the advantages of Information and communication technology (ICT) are believed that they lead this sector from the gloomy age to a golden era [2] (Suryani, 2010) because implementing ICT in schools has brought considerable promise. Furthermore, teachers believed that ICT could offer a useful language environment for students, lively activities, and share knowledge with other colleagues (Nhu, Keong, \& Wah, 2018) [3]. Likewise, ICT could enhance the capacity of school stakeholders and school leaders in the entire school ecosystem (Razak, Jalil, Krauss \& Ahmad, 2018 [4]; Razak, Ab Jalil, \& Ismail,2019 [5]). Moreover, ICT could render students more dynamic and collaborative (Moodiel, 2000[6]; Suryani, 2010[2]) as well as enhance students' motivations (Davies, C., \& Birmingham) [7], children's literacy (Adonis, 2006) [8], and meta-cognitive learning (Monteith, 2002) [9].
On the other hand, the cutting-edge of Web 2.0 has resulted in a proliferation of prominent social media applications such as Twitter, YouTube, Snapchat, Facebook, Instagram, WhatsApp, Kakao Talk, and so on, whereby abundant opportunities of connection have been offered to virtual users to stay connected locally and internationally regardless of sociocultural and socioeconomic backgrounds. At the current time,

certain terms such as websites, blogs, and social media are no longer too strange to all individuals in various settings. Students, teachers, and researchers in ELT maybe are no exception. Further, learning English in this digital world may not mean that schools focus not only on formal education or stereotyped methodologies. In other words, it seems to be unnecessary to pin ELT with the traditional context in which pens and paper, books are the profound tools for education. The fact that among the stream of wellknown SNSs has been launched onto the market in recent decades, the prevalence of SNSs, especially Facebook is indisputable. Based on Figure 1 below from Clement (2020) [10], Facebook has still kept the most widespread and frequently used social media around the world for long. There has been also a range 
of empirical studies conducted to elucidate the impacts of SNSs and Facebook worldwide in education such as Lafford (2009) [11], Kirschner \& Karpinski (2010) [12], Junco (2012 \& 2015) [13-14], Nkhoma, Cong, $\mathrm{Au}$, Lam, Richardson, Smith, R., \& El-Den (2015) [15], Kitchakarn (2016) [16], Akhiar, Mydin, \& Kasuma, (2017) [17], Abrahim, Mir, Suhara, \& Sato, (2018) [18], Adi \& Ai (2019) [19], Nguyen ( 2019) [20], Avila, \& Cabrera, (2020) [21], Puimom (2020) [22], Siddig (2020) [23], and Wongsa \& Son (2020) [24].

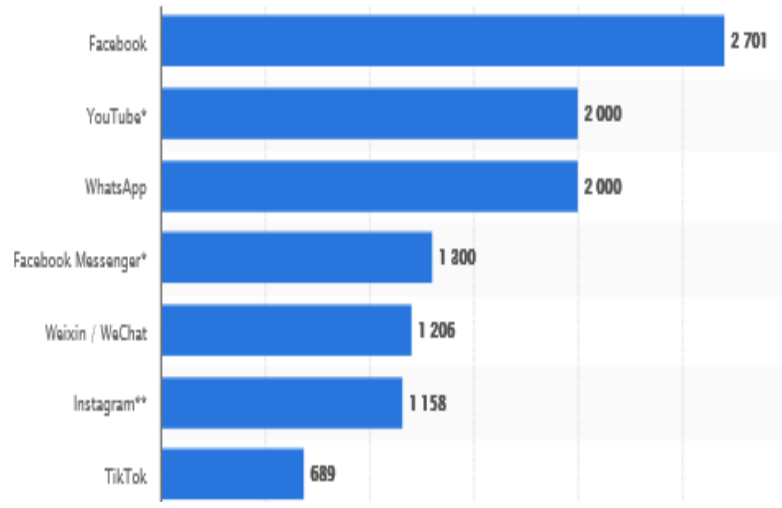

Figure 1: Global social networks ranked by a number of users 2020 (Clement,2020).

In Viet Nam, as being compared with other domestic and foreign SNSs, Facebook has been the most widespread media among other SNSs (Đạt, 2020) [25]. It is also being used by language students and teachers for educational purposes (Thao \& Dieu, 2020) [26]. Nonetheless, there are several studies have been conducted to explore the impact of Facebook on ELT (Tuân \& Tư, 2013 [27]; Tran, 2016 [28];Van \& La, 2017 [29]; Nhi \& Mai,2018[30]; Le, 2018[31]; Ngo, 2018 [32]; Huong, Oanh.T., Oanh. K., \& Luong, 2019 [33]; Loan, 2019[34]; Thao \& Dieu, 2020 [26]; Vu \& Bui, 2020 [35]; Nguyen, 2017 [36]). Hence, this study was conducted, and the overall aim of this study expected to open a room so that it would shed light on the attitudes to use of Facebook among English- major students in Vietnam.

\section{Research Questions}

RQ1: What are EFL Vietnamese students' perceptions of the general Ease of Facebook Use for English language learning?

RQ 2. What are EFL Vietnamese students' attitudes toward the Usefulness of Facebook for engaging in specific activities for language learning?

RQ3. Do the Vietnamese students consider Facebook as an online learning environment that facilitates their language learning? If yes, in which specific skills or aspects?

\section{LITERATURE REVIEW}

\subsection{Technology Integration in ELT}

According to Prensky (2001) [37], who coined originally the terms students as "digital natives" and teachers as "digital immigrants", students today who were born in recent years of latest digital technology immerse their life with digital gadgets such as cell phones, digital music players, all toys and devices of the digital age. As a result, besides mastering certain digital computer literacy among them, ICT seems to cause this generation of learners to rely deeply on it (Woodcock, Middleton, \& Nortcliffe,2012 [38]; Samaha \& Hawi, 2016[39]; Ahad \& Anshari,2017 [40]); Hasmawati, Samiha, Razzaq \& Anshari, 2020[41]). Nonetheless, the majority of teachers were not born in the same period. Hence, teachers not only need experience ICT tools but adapt to be equipped with computer skills to leverage ICT for educational aims (Omar, Embi, Yunus, 2012 [42]; Kessler \& Hubbard, 2017 [43]).

There has been a vast number of studies have been conducted to investigate the impacts of using of ICTs in the education system as well as students' perceptions towards ICTs (Lafford, 2009[11]; Ping \& Maniam, 2015 [44]; Shafie, Yaacob, \& Karpal Singh, 2016 [45]; Sun, You, Shen, Luo, 2017 [46]; Akhiar, Mydin \& Kasuma (2017) [17]; Karim, Mallah, Laghari, Madiha, \& Larik, 2019 [47]; Ahmed, Mustaffa,\& Rani, 2020 [48]; Inpeng, \& Nomnian, 2020 [49]; Ganapathy, Kabilan, \& Meenakshisundram, 2020 [50]; Siddig, 2020 [23]). Hence, the concept of technology integration in teaching may basically understand that how people utilize technologies to promote learning and educating for both learners and teachers in language aptitude.

\subsection{Social Networking Sites (SNSs) in ELT}

Aydin (2012) [51] stated that SNSs enable plenty of users to serve the aims of maintaining social relationships in congruence with their interests as well as concerns. In other words, SNSs provide abundant chances for users around the world to connect to each other regardless of sociocultural and socioeconomic backgrounds. Various application names such as Instagram, LinkedIn, WhatsApp, YouTube, Twitter, Facebook, and others have been proliferated constantly and enter every corner of the world. These cyberplatform applications influence remarkably almost all aspects of modern humans. Thus, the fact is that SNSs integration in education today is surely foreseeable in which language discipline is inevitable. According to (Blattner \& Fiori, 2009) [52], SNSs could promote students' learning by offering chances to connect with teachers and native speakers. The finding of the study by Alnujaidi (2017) [53] indicated that postgraduate students in Saudi Arabia revealed that they had positive perceptions, attitudes, as well as expectations of SNSs, including YouTube, Twitter, and Instagram. In much 
the same way, Martynova, Poddubnaya, Ostrovskaya, Zdor, \& Lomonosova, (2020) [54] and Kumar \& Syed (2020) [55] indicated that SNSs increased students' motivation, vocabulary, assisted in improving grammar proficiency among non-linguistic students. Further, Sumardi \& Muamaroh (2020) [56] discussed Edmodo's positive impact in mediating digital language classroom and assessment. The result indicated that this application facilitated Indonesian participants' involvement and enhanced student-centered learning activities. In respect to English teacher education, Ketabi and Kavoshian (2017) [57] argued that Mobile Social Network Sites played a paramount role in teacher education in Iran. And Guikema and Menke (2014) [58] investigated how to incorporate and develop digital skills for language teacher programs. A study by Ganapathy, Kabilan, \& Meenakshisundram (2020) [50] proved that Facebook contributed positively to professional development activities in Penang, Malaysia. Some suggestions from Kessler, G., \& Hubbard, P. (2017) [43] that teachers need to be ready for ultilizing ICT and SNSs - based teaching for ELT development for themselves and their students.

Nevertheless, there are some studies indicated that students felt reluctant to engage Facebook- based activities because uploaded contents were unhelpful and irrelevant to the topics they concerned (Kasuma \& Wray, 2015) [104] or Chen (2016) [105] discussed that there were not effective methodologies were delivered to all students on the Facebook group by English teachers.

\subsection{Facebook in ELT in Vietnam context}

According to Clement (2020) [59] in Figure 2, the monthly number of Facebook active users till November of 2020 was recorded worldwide are more than 2.7 billion. India claimed the first position with the highest number of Facebook users with 310 million users, followed by the United States, Indonesia, Brazil, Mexico, The Philippines, Vietnam, Thailand, Egypt, and Bangladesh. It can be seen from Figure 2 that Vietnam, with 65 million users, accounted for the $7^{\text {th }}$ position and the $3^{\text {rd }}$ position in Southern East Asia. Practically, Facebook has been the most powerful domain among prevalent SNSs in recent years. Thus, this ranking report pointed out that Facebook may own a certain potential in Vietnam.

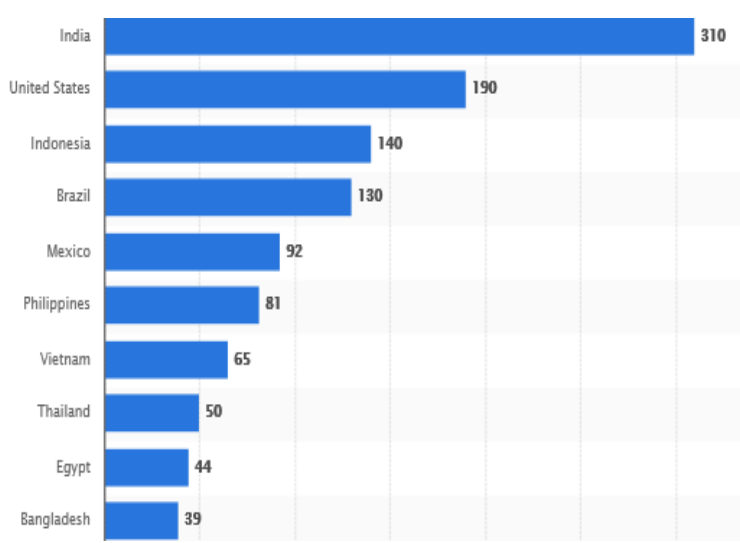

Figure 2. Leading countries based on number of Facebook users in millions (Clement, 2020)

There have been wide-ranging studies regarding ELT discipline was conducted internationally. Despite the connection of rocketing emergence of Facebook in conjunction with the powerful position of Facebook in Vietnam context from the recorded data of Đạt (2020) ([25], limited numbers of studies have been carried out to explore how Facebook platform impacted upon ELT in Vietnam. Typically, Tuân \& Tư (2013) [27] advocated that Facebook had a huge influence on students' study in North region of Vietnam. Facebook was a bridge that connected students themselves for private classroom communication, lessons, assignments, other school-related purposes, learning outcomes, and students- instructors relationship. Even students could adapt to school culture and school life easily via Facebook. Le (2018) [31] substantiated that students utilized Facebook to socialize and learn English, such as resource sharing to improve language proficiency and subject-related discussion for life-long learning and autonomy. Another study by Van \& La (2017) [29] attempted to indicate that through the Facebook site, Vietnamese students' motivation was changed positively when teachers used Facebook for EFL courses. Additionally, Thao and Dieu (2020) [26] upheld that by using through Facebook - based activities, both male students and female students showed positive affection for English learning. In relation to improving language skills, Nhi \& Mai (2018) [30] supported that there were significant shifts in vocabulary and grammar, and writing abilities among high school students in the Mekong Delta region. In a similar vein, a partial result of $\mathrm{Vu} \&$ Bui (2020) [35] was reported that tertiary students' writing competence was improved when Facebook was a component of the blended learning approach. In addition, the result from the study of Huong, Oanh, T., Oanh K., \& Luong (2019) [33] presented that Facebook could level up English - major students' pronunciation. 


\subsection{Theory of Facebook Usage for Education (Mazman and Usluel, 2010)}

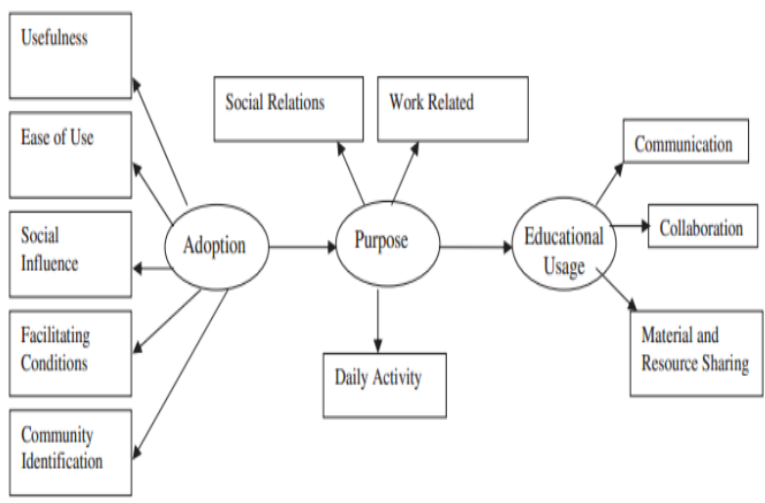

Figure 3. The model of Educational Usage of Facebook (Mazman \& Usluel,2010).

Mazman and Usluel (2010) [60] designed the structural equation model for using Facebook among a group of 606 Turkish university learners, in which the Usage for Educational purposes was an integral part of the model. Based on Figure 3, it was postulated that there were 3 latent variables of adoption, purposes, and educational usage. 11 observable variables surrounded each. In relation to Facebook Adoption, Mazman and Usluel (2010) [60] pointed out that Usefulness, Ease of Use, Social Influence, Facilitating Conditions, Community Identification were the noticeable features that students favored. In terms of Educational Usage, the study indicated that Facebook helped students interact, collaborate, and share subject materials. Nonetheless, regarding the study's scope, there were only two variables of Adoption that were highlighted comprizing Usefulness and Ease of Use, and both were served for Educational Usage. This early model was reviewed to refine in some past studies where the finding was found in studies such as Nasri \& Charfeddine, (2012) [61]; Sánchez, Cortijo, Javed (2014) [1]; Da Rocha, Conradie, \& Lombard (2014) [62]; (Jin, 2015) [63]; Manasijević, Živković, Arsić, \& Milošević, (2016) [64]; Nguyen (2017) [36]; Shefketi \& Hamiti (2019) [65].

\subsection{Technology Acceptance Model (Davis, 1989).}

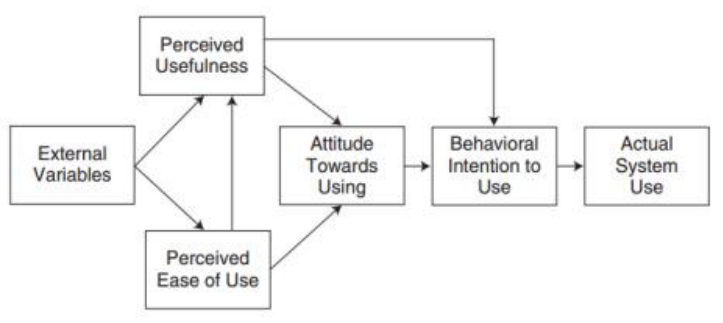

Figure 4. Technology Acceptance Model (Davis, 1989).
According to Davis (1989) [66], this model was constructed to predict ICT adoption in different settings. Two focal components resulted in individuals' Actual Usage of ICT namely Perceived Ease of Use and Perceived Usefulness. These two elements were correlated to each other, leading to Attitudes to Use and Intention to Use. In line with it, additional definitions by Park (2009) [67], Teo, (2009 [74]), in the three three factors Perceived Usefulness (PU), Perceived Ease of Use (PEoU), and Attitudes toward Usage (AtU), PEoU highlighted views of the ease of utilizing technology in learning, PU provided the view of users that they benefit from technology. Last, AtU was proposed was the perception of how technology was viewed. ATU was influenced by PEoU (Park, 2009 [67]; Chang, Yan, \& Tseng, 2012 [68]). And PEOU had a significant impact on PU (Adwan, Adwan, \& Smedley, 2013 [69]; Shroff, Daneen, \& Eugnenia, 2011 [70]). Teeroovengadum, Heeraman, \& Jugurnath (2017) [71] also applied TAM for ICT adoption in education and found out students' qualification and background as external variables did matter to some extent but were made insignificant as PU and PEoU were added. Additionally, PU and PEoU influenced ICT adoption in the teaching and learning in secondary schools in Mauritius. A study by Cakır and Solak (2015) [72] posited that there was a positive affection on estudents' academic performance in terms of Ease of Use, satisfaction, and self-efficacy when the technology was an essential tool for learning. For the sake of larger scale, Lee (2010) [73] synthesized TAM, the expectation-confirmation model, and the theory of planned behavior to propose a theoretical model to predict students' intentions for e-learning and found out positive results in which satisfaction played the most significant influence on students' intention, followed by students' perceived usefulness, attitude, attention, and subjective rules.

\subsection{THEORETICAL FRAMEWORK}

The current study was conducted to explore undergraduates' attitudes towards the use of Facebook for ELT. As shown in Figure 5, it was advocated that Facebook users could communicate, collaborate and share and exchange learning resources with their fellows. As a result, users perceived the Usefulness as well as Ease of Use of Facebook. This affection may be considered as their attitudes to Facebook's language development tool. It may affect their language competence and attitudes, motivations, and behaviors differently. 


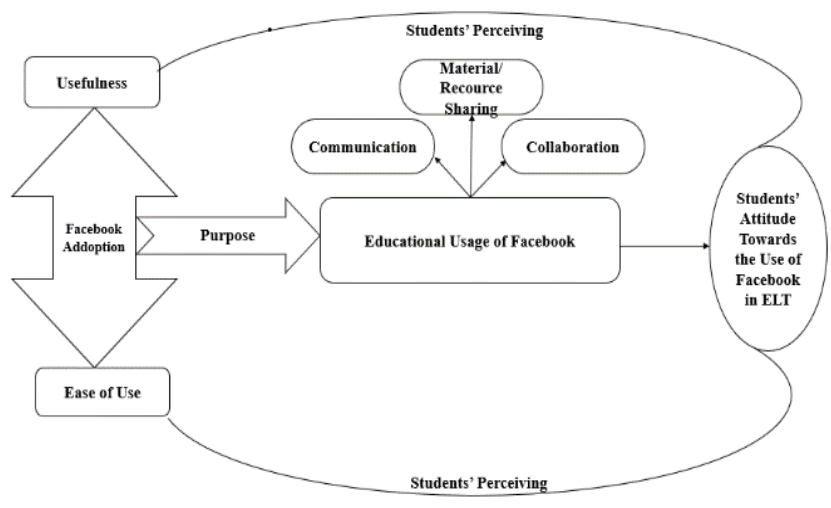

Figure 5. Framework

To fulfill the aim of the study, thus, one framework was constituted that was adapted from both TAM model (Davis, 1989) [66] and The Model of Facebook Usage (Mazman and Usluel, 2010) [60] as the underpinning theories. This framework is expected to gain insights into the Vietnamese students' attitudes towards Facebook use in English learning.

\section{METHODOLOGY}

\subsection{Population and Sampling}

The current study is quantitative research in which data were collected by measuring the participants' responses from questionnaires. The participants encompassed 323 Vietnamese undergraduates in that 90 males $(\mathrm{n}=28 \%)$, and 233 females $(\mathrm{n}=72 \%)$, studying in three fields of English studies, namely, Teaching, Business, and Translation and Interpretation from several universities on a voluntary basis in Hochiminh City, the South region of Vietnam. However, participants of origin were various along with Vietnam. The official Vietnamese language is their first language and English as a foreign language (EFL). In addition, all participants owned their active Facebook accounts as a prerequisite of the surveying procedure. Last but not least, all information of the participants was kept for only the research purpose and confidential by the researcher.

\subsection{Research Instruments}

The study was conducted based on a quantitative method. The instruments used in was adapted from Kabilan, Ahmad, \& Abidin, (2010) [74], Gamble \& Wilkins (2014) [75], There are three sets of the entire data, and the first two sets consisted of 10 statements. The first two set aimed to discuss the students' feedbacks on using Facebook for general educational purposes, while the second one was to examine opinions on the applicability of Facebook for language activities. More particularly, in section 1, the first two statements were related to both aspects of social behaviours and education. The third and the fourth statements triggered students to compare the accessibility of Facebook from phone and website, while the fourth one also aims to compare seeking for school news on Facebook and phones. The rest of 6 statements concerned language learning management. In section two, with ten statements, participants were designed to judge the effectiveness of using Facebook to deliver various activities that strengthen language skills and other aspects such as peer-review and taking notes. All statements were constructed on a 7 - level Likert scale ranged 1(Strongly Disagree) to 7 (Strongly Agree) and level 4 as a neutral level. Section 3, with 16 statements were to seek students' feedback on practicing on Facebook to facilitate learning skills, confidence, attitudes, and motivations. This construct used a 5-level Likert scale. The reliability test results of Sections 1,2 , and 3 were $0.9,0.7$, and 0.8 , respectively.

\subsection{Data Analysis}

Data were statistically recorded and analyzed by using SPSS. Data were first grouped and analyzed quantitatively based on means and standard deviations. For sections 1 and 2, the ranges of choices were scored from 1 (Strongly Disagree) to 7 (Strongly Agree) on a Likert scale in which 4 were labeled as neutral level. In order to describe the results as the ease of elucidation, the results formed the questionnaire were classified and merged into a three-point scale that was Disagree (from 1 to 3,) Neutral(4), and Agree (5 to 7). Section 3 about fulfilling RQ 3, choices ranged from 1 (Strongly Disagree) to 5 (Strongly Agree) on a Likert scale, and 3 represented as Neutral degree. After Descriptive analysis, percentages were formed to lead to the research findings.

\section{FINDINGS AND DISCUSSIONS}

4.1 RQ1: What are EFL Vietnamese students' perceptions of the general ease of Facebook use for English language learning?

The statements were categorized into 3 groups, including Ease of Use (Statement 1-4), Educational Use (Statement 4-7), Instructional Use (Statemen 8-10). Then, the percentage would be found in Table 1 below.

Table 1. Mean and Standard Deviation of Students' Perceived Ease of Use of Facebook

\begin{tabular}{|l|l|l|}
\hline Category & Mean & S.D \\
\hline $\begin{array}{l}\text { Ease of Use } \\
\text { (Statement 1-4), }\end{array}$ & 4.64 & 1.36 \\
\hline $\begin{array}{l}\text { Educational Use } \\
\text { (Statement 5-7) }\end{array}$ & 5.27 & 1.41 \\
\hline $\begin{array}{l}\text { Instructional Use } \\
\text { (Statement 8-10) }\end{array}$ & 4.97 & 1.40 \\
\hline
\end{tabular}


Table 2 below shows that the percentage of each category in terms of Agree level was more than 50\%. Apart from percentages, the means of Educational Use,
Instructional Use, and Ease of Use were 4.64, 4.97, and 5.27 , respectively, indicating that participants believed the general Ease of Use positively.

Table 2. The frequency data of the participants' perception of the general ease of using Facebook

\begin{tabular}{|c|c|c|c|c|}
\hline & Statements & $\begin{array}{l}\text { Disagree } \\
(\%)\end{array}$ & $\begin{array}{l}\text { Neutral } \\
(\%)\end{array}$ & $\begin{array}{l}\text { Agree } \\
(\%)\end{array}$ \\
\hline \multirow{4}{*}{$\begin{array}{l}\text { Ease of } \\
\text { Use }\end{array}$} & 1. Facebook can be served for both socially and for educational purposes. & 10.5 & 34.1 & 55.4 \\
\hline & 2. Facebook is safe to use both socially and for educational purposes & 26 & 37.7 & 36.3 \\
\hline & $\begin{array}{l}\text { 3. Facebook is easier to access from the mobile phone than the own } \\
\text { university's website. }\end{array}$ & 15.1 & 22.9 & 62.8 \\
\hline & $\begin{array}{l}\text { 4. Facebook is easy and convenient to find school-related information than my } \\
\text { own university website. }\end{array}$ & 17.6 & 27.6 & 54.8 \\
\hline \multirow{3}{*}{$\begin{array}{l}\text { Educati } \\
\text { onal Use }\end{array}$} & 5. It is easy to make posts, upload pictures and videos on Facebook. & 8.6 & 8.9 & 72.5 \\
\hline & 6. Facebook is a site to keep in contact with other students from class. & 10 & 17.0 & 73.0 \\
\hline & 7. Facebook is a place to contact my teacher outside of class & 11.0 & 22.0 & 67.0 \\
\hline \multirow[t]{3}{*}{$\begin{array}{l}\text { Instructi } \\
\text { onal Use }\end{array}$} & $\begin{array}{l}\text { 8. Facebook is a site to check class notes or homework assignments posted by } \\
\text { the teacher }\end{array}$ & 13.9 & 19.2 & 66.9 \\
\hline & 9. Facebook is a site to ask for help with homework assignments. & 12.7 & 25.1 & 66.2 \\
\hline & $\begin{array}{l}\text { 10. Facebook is a site to check for school-related updates } \\
\text { and notices. }\end{array}$ & 15.5 & 23.8 & 60.7 \\
\hline
\end{tabular}

As shown in Table 2, for the first factor, Facebook's Educational Use, this was also the aspect accounting for the highest and expressive percentage among three general Ease of Use of Facebook. In particular, there were $73 \%$ of participants agreed that Facebook was a site for them to keep in touch with their mates (Statement 6). And similarly, $72.5 \%$ of them affirmed that they could share posts and upload pictures, and videos through their Facebook accounts (Statement 5). Additionally, $67 \%$ of them believed that they could keep in touch with their instructors via Facebook beyond the classroom context (Statement 7). The finding was in line with Mazer, Murphy, and Simonds (2007) [76] that found that Facebook enabled teachers as well students to make interpersonal connections with each other. To be compared with the previous time when SMS and phone calls were still priorities, Facebook is free of charge except for Internet broadband or Wifi added. And at present, it has been concurred that Facebook could be a suitable choice for not only general users but also ELT people like students and instructors.

Relating to Ease of Use, as defined by Davis (1989) [66], Thompson, Higgins \& Howell (1991) [77], and Rogers (2003) [78], Ease of Use was the various degrees of individuals believing that employed a certain system served their own purposes beneficially. This study's level of percentages could be certain systems served their own purposes beneficially. The level of percentages in this study could be understood that Facebook is conducive and practical for students in English learning. Particularly, from Table 2, 62.8\% of participants considered Facebook easier to access functionally on mobile phones than the university's website (Statement 3). Next, $55.4 \%$ of participants realized that Facebook could be for socializing as well as educational purposes (Statement 1). Further positive feedback from $54.8 \%$ of participants also represented that it was convenient for them to get school's information on Facebook compared with their university websites (Statement 4). The finding was supported by the results of Ractham and Firpo (2011) [79], and Kitchakarn (2016) [16] substantiated that Facebook is a friendly environment for language students to explore information.

Concerning Instructional Use, $66.9 \%$ of responses agreed that students could check classroom notes or assignments of their teachers on Facebook (Statement 8 ). As follows, $66.2 \%$ of students considered Facebook is an assisting site to complete assignments delivered by instructors. Also, $60.7 \%$ of the total revealed that besides traditional announcements from school through the traditional method such as notice boards and emails, and face-to-face notices, Facebook platform offered a further choice for students to refer the school's notices in the digital era (statement 10). These findings consistent with previous research such as Gamble and Wilkins (2014) [75], Karimi, Ahmad, Khodabandelou (2013) [80], Akbari, Eghtesad, and Simons (2012) [81] where students' perceived mainly and learning outcomes were significant as a result of using Facebook to seek for classroom materials and resources. 
All in all, from the means of data on Table 1 (4.64, 4.97, 5.27), it could be understood that students perceived the general ease of using Facebook in an educational context positively, especially for Educational Use. Hence, it is posited that Facebook-based language

RQ 2. What are EFL Vietnamese students' attitudes toward the Usefulness of Facebook for engaging in specific activities for language learning?

The data were categorized into three distinct groups. The first one (statements 1, 6, 8, and 10) was Interpersonal Communication, the second category was named Interpretive Communication (statements learning could be a useful educational tool cultivating students' interests in the learning process. This is understood that language students and instructors could leverage this strength of Facebook for better methodology or educational purpose.

$3,4,5,9)$, and the last group was Presentational Communication (statements 2 \& 7). Table 3 below presented the Mean score and Standard Deviation of students' attitudes toward the usefulness of Facebook in specific activities for language learning. Table 4 would present the frequency data of the participants' attitudes toward the usefulness of Facebook in specific activities for language learning.

Table 3. Mean and Standard Deviation of students' attitudes toward the usefulness of Facebook in specific activities for language learning

\begin{tabular}{|c|c|c|c|c|}
\hline Category & Statements & Disagree $(\%)$ & Neutral $(\%)$ & Agree( $\%)$ \\
\hline \multirow{4}{*}{$\begin{array}{l}\text { Interpersona } \\
1 \\
\text { Communica } \\
\text { tion } \\
\text { (statements } \\
1,6,8 \text {, and } \\
10 \text { ) }\end{array}$} & 1. Facebook is a site to discuss different topics with classmates. & 5.6 & 34.1 & 60.4 \\
\hline & $\begin{array}{l}\text { 6. Facebook is a site to have discussions with "guest speakers" } \\
\text { like international students. }\end{array}$ & 26 & 37.7 & 55.8 \\
\hline & $\begin{array}{l}\text { 8. Facebook is a site to peer review or peer edit classmates' } \\
\text { writing assignments }\end{array}$ & 21.9 & 22.9 & 55.2 \\
\hline & 10. Facebook is a site to post and respond to surveys. & 10.2 & 22.7 & 67.2 \\
\hline \multirow{4}{*}{$\begin{array}{l}\text { Interpretive } \\
\text { Communica } \\
\text { tion } \\
\text { (statement } \\
3,4,5,9) \text {, }\end{array}$} & $\begin{array}{l}\text { 3. Facebook is. a site to read articles and take notes to prepare } \\
\text { for next class }\end{array}$ & 21.0 & 30.7 & 48.3 \\
\hline & $\begin{array}{l}\text { 4. Facebook is a site to listen to the audio files, and take note to } \\
\text { prepare for the next class }\end{array}$ & 22.9 & 33.4 & 43.7 \\
\hline & $\begin{array}{l}\text { 5. Facebook is a site to access links to resources provided by the } \\
\text { teacher. }\end{array}$ & 19.6 & 17.0 & 63.4 \\
\hline & $\begin{array}{l}\text { 9. Facebook is a site to watch Youtube videos and discuss } \\
\text { comprehension } \\
\text { questions with classmates }\end{array}$ & 18.3 & 26.0 & 55.7 \\
\hline \multirow{2}{*}{$\begin{array}{l}\text { Presentation } \\
\text { al } \\
\text { Communica } \\
\text { tion } \\
\text { (statements } \\
2 \text { \& } 7 \\
\end{array}$} & 2. Facebook is a site to make video posts as assignments. & 12.1 & 29.7 & 51.9 \\
\hline & $\begin{array}{l}\text { 7. Facebook is a site to post writing assignments like short stories } \\
\text { or essays }\end{array}$ & 18.9 & 25.4 & 66.2 \\
\hline
\end{tabular}

Table 4. Participants' attitudes toward the usefulness of Facebook in specific activities for language learning

\begin{tabular}{|l|l|l|}
\hline Category & Mean & S.D \\
\hline $\begin{array}{l}\text { Interpersonal Communication } \\
\text { (statements 1, 6, 8, and 10) }\end{array}$ & 4.80 & 1.34 \\
\hline $\begin{array}{l}\text { Interpretive Communication (statement } \\
3,4,5,9),\end{array}$ & 4.59 & 1.43 \\
\hline $\begin{array}{l}\text { Presentational Communication } \\
\text { (statements 2 \& 7 }\end{array}$ & 4.73 & 1.32 \\
\hline
\end{tabular}

The result from Table 3 and Table 4 revealed that attitudes among participants towards learning activities on Facebook were positive through 3 aspects as the following.

\section{Interpersonal Communication}

The result of Statement 10, "Facebook is a site to post and respond to surveys" was accounted for $67.2 \%$ as the highest point for not only this sub-category but also for the whole data of the usefulness in each of specific activities for the English language learning. Furthermore, the result of Statement 1 "Facebook is a site to discuss different topics with classmates," was $60.2 \%$ indicated that participants could feel satisfied and get into a conversation with each other about informal themes on Facebook such as life, food, interests and so on. This was consistent with Kitchakarn (2016) [16] and Arendt, Matic, \& Zhu (2012) [82] where students believed that Facebook was thought of as a better environment for unacademic stories. Thus, it could be seen that Interpersonal Communication could be one of the leading respects of 
Usefulness in specific activities for language learning on Facebook platform, and powerful factor of Facebook for students' language development.

\section{Interpretive Communication}

The result of statement 5 (63.4\%), "Facebook is a site to access links to resources provided by the teacher", reported that it was the highest point in expressing attitudes to the respect of Interpretive Communication. On the other hand, $55.7 \%$ of participants' feedback confirmed that students could watch Youtube and exchange comprehension questions with their peers. This occurred because of the fact that Facebook has a function enabling all its users to watch short clips, whole videos, or movies randomly or intentionally. This perhaps attracts Facebook users to engage in watching them quite often and learn the language in reality. Hence, it could be admitted that Interpretive Communication is also one of the major components of ultilising Facebook application for language classroom to improve students' self-study. The general finding was in line with Thao's (2018) [82] where tech-based learning activities are one of components enhanced Vietnamese students' autonomy. The similar finding from Gamble and Wilkins (2014) [75] supported that students' attitude towards Interpretive Communication was changed positively among Japanese students towards using Facebook in learning English.

\section{Presentational Communication}

Apart from other categories such as Interpretive Communication and Interpersonal Communication

\section{RQ3. Do the Vietnamese students consider} Facebook as an online learning environment that facilitates their language learning? If yes, in which specific skills or aspects?

The statements were categorized into 3 groups including Language skill improvements (statements 1, 2,3,4), Confidence (statement 5,6,7), Motivation (statements 8,9, 10, 11,12), Attitude (Statement 13,14,15,16). Table 5 below presented Mean and Standard Deviation of whether Facebook is an online learning environment. And Table 6 would show the frequency data of considering Facebook as an online learning environment facilitating their language learning. therein, this Presentational Communication classification revalidated that participants' feedback on using Facebook platform as a Presentational Communication for language acquisition was also highly positive. Based on the result of statement 7 as the second-highest ranking $(66.2 \%)$ in the sub-section, "Facebook is a site to post writing assignments like short stories or essays", the Presentational Communication aspect on Facebook seemed to practically beneficial to serve for language learning as a supplementary essence besides the pen and paper traditional method or offline classroom space in the previous time. To prepare such stories or essays uploaded, students attempted to practice the brainstorming skill, or at least they need certain vocabularies. This meant that participants seemed to focus thoroughly on their uploading quality. The finding was partially similar to Kitchakarn (2016) [16] that was corroborated that students expressed positive attitudes to the Usefulness of Facebook-based language activities in terms of Presentational Communication. Similarly, Gamble and Wilkins (2014) [75] supported that students' attitudes towards Presentational Communication are highly positive. Likewise, Shafie, Yaacob, \& Karpal Singh (2016) [45] validated that posting writing in English on Facebook was the most favorite activity among students.

In short, by analyzing students' attitudes through three categories namely Interpretive Communication, Presentational, and Interpersonal Communication. Once, Facebook could be a beneficial site for both EFL students and teachers.

Table 5: Mean and Standard Deviation of whether Facebook is an online learning environment

\begin{tabular}{|l|l|l|}
\hline Category & Mean & S.D \\
\hline $\begin{array}{l}\text { Language skill improvements } \\
\text { (Statements 1,2,3,4) }\end{array}$ & $\mathbf{3 . 5 9}$ & $\mathbf{1 . 3 4}$ \\
\hline $\begin{array}{l}\text { Confidence (Statement 5,6,7) } \\
\begin{array}{l}\text { Motivation (Statements 8,9, } \\
\text { 10,11,12) }\end{array}\end{array}$ & $\mathbf{3 . 6 4}$ & $\mathbf{1 . 4 3}$ \\
\hline $\begin{array}{l}\text { Attitude (Statement } \\
13,14,15,16)\end{array}$ & $\mathbf{3 . 7 6}$ & $\mathbf{1 . 3 2}$ \\
\hline
\end{tabular}


Table 6: The frequency data of considering Facebook as an online learning environment facilitating their language learning

\begin{tabular}{|c|c|c|c|c|c|c|}
\hline & Statement & $\begin{array}{l}\text { Strongly } \\
\text { Disagree } \\
(\%)\end{array}$ & $\begin{array}{l}\text { Disagre } \\
\text { e }\end{array}$ & $\begin{array}{l}\text { Slightly } \\
\text { Agree }\end{array}$ & Agree & $\begin{array}{l}\text { Strongly } \\
\text { Agree }\end{array}$ \\
\hline \multirow{4}{*}{$\begin{array}{lr}\text { Language } & \text { Skill } \\
(\text { Statements } & 1, \\
2,3,4) & \end{array}$} & 1. Practice writing in English & 3.4 & 9.0 & 34.1 & 42.4 & 11.1 \\
\hline & 2. Practice reading in English & 0.6 & 6.5 & 25.1 & 47.7 & 20.1 \\
\hline & $\begin{array}{l}\text { 3. Practice and enhance students' English } \\
\text { communication skills }\end{array}$ & 3.1 & 8.0 & 26.6 & 42.4 & 19.80 . \\
\hline & 4. Tolerate language mistake & 4.6 & 12.1 & 39.0 & 29.7 & 14.6 \\
\hline \multirow[t]{3}{*}{$\begin{array}{l}\text { Confidence } \\
\text { (Statement 5,6,7) }\end{array}$} & $\begin{array}{l}\text { Enhance students' confidence to write in } \\
\text { English }\end{array}$ & 2.5 & 10.5 & 31.0 & 38.7 & 17.3 \\
\hline & $\begin{array}{l}\text { Enhance students' confidence to read } \\
\text { English materials }\end{array}$ & 1.5 & 8.4 & 32.2 & 39.0 & 18.9 \\
\hline & $\begin{array}{l}\text { Enhance students' confidence to } \\
\text { communicate using English }\end{array}$ & 2.2 & 9.9 & 27.6 & 26.8 & 23.5 \\
\hline \multirow{5}{*}{$\begin{array}{l}\text { Motivation } \\
\text { (Statements } 8,9 \text {, } \\
10,11,12)\end{array}$} & $\begin{array}{l}\text { Enhance student's motivation to } \\
\text { communicate using English }\end{array}$ & 1.9 & 10.5 & 30.0 & 33.4 & 24.1 \\
\hline & $\begin{array}{l}\text { Enhance students' motivation to read } \\
\text { English materials }\end{array}$ & 2.2 & 8.4 & 26.0 & 42.1 & 21.4 \\
\hline & $\begin{array}{l}\text { Enhance students' motivation to write in } \\
\text { English }\end{array}$ & 4.6 & 9.9 & 31.0 & 39.3 & 15.2 \\
\hline & Make learning English more interesting & 2.8 & 9.6 & 17.0 & 39.0 & 31.6 \\
\hline & Make learning English easier & 1.9 & 9.9 & 32.2 & 38.7 & 17.3 \\
\hline \multirow{4}{*}{$\begin{array}{l}\text { Attitude } \\
\text { (Statement } \\
13,14,15,16)\end{array}$} & Learning English generally & 2.8 & 4.0 & 23.2 & 43.0 & 26.9 \\
\hline & $\begin{array}{l}\text { 13. Inculcate a more positive attitude } \\
\text { towards learning English as a foreign } \\
\text { language }\end{array}$ & 4.3 & 7.4 & 33.4 & 36.8 & 18.0 \\
\hline & $\begin{array}{l}\text { Inculcate a more positive attitude towards } \\
\text { learning English as a } \\
\text { language }\end{array}$ & 2.5 & 9.9 & 34.1 & 35.6 & 18.0 \\
\hline & Learn vocabulary ability in English & 2.2 & 3.7 & 17.3 & 43.7 & 33.1 \\
\hline
\end{tabular}

As shown in Table 5 with classifications of general opinions of students on whether Facebook facilitates language learning, though the mean scores for all the items did not reach 4.0, the total percentage of participants in the scale of agreed and strongly agreed level exceeds at least $50 \%$ for all excepted for the item 4. Thus, for fluid analysis and data expounding, that would contribute to the discussion part of the use of Facebook in English learning.

From Table 6, the participants agreed that Facebook could be an online site to practice English proficiency, in which reading skills accounted for $67.8 \%$ of all. To leverage Facebook for communication skills, $62.2 \%$ of participants verified that Facebook might be a site for users to effectively practice English. This was in line with Puimom (2020) [22] when Thai Students' English speaking skill was increased by uploading clips on Facebook during their course. Bachate (2016) [84] proved that language laboratories positively impacted students' communication skills and speaking skills as multimedia was used in teaching English in India. Similarly, Sun, You, Shen, Luo (2017) [46] highlighted that SNSs enhanced EFL learners" speaking skills in China.
Relating to writing skill, $53.5 \%$ of participants believed that their writing changed positively thanks to the presence of Facebook for their English learning. The finding was consistent with the previous studies (Nhi \& Mai, 2018 [30]; Aydin, 2012 [51]; Aydin (2014) [85], Adwan , Adwan \& Smedley (2013) [69]; Shroff, Deneen,\& Eugenia (2011) [70], Ping \& Maniam (2015) [44], Kitchakarn (2016) [16], Rodliyah (2016) [86], Wongsa \& Son (2020) [24] that supported that using Facebook for writing skill was perceived positively so that it facilitated students' writing ability. In other regard, Majid, Stapa, \& Keong (2015) [87], Vu \& Bui (2020) [35] found out that Facebook made students improve writing process and writing outcomes as blended scaffolding strategies were employed through Facebook. Furthermore, McCALL (2017) [88] found that Facebook's microblogs fostered students' both academic reading and writing skills throughout the English for Academic Program. Additionally, Kumar and Syed (2020) [55] found that Pakistan learners' competence improved in terms of reading, writing, vocabulary, and grammar.

Concerning practicing English without making mistakes (44.3\%), learners are free and unembarrassed to use English on the Facebook platform instead of a 
classroom. This finding of this study was supported by Nadzrah and Mickan (2003) [89], Gannon-Leary and Fontainha (2007) [90], Siddig (2020) [23] that students were optimistic in practicing the English language on Social Media compared with the traditional classroom setting.

\section{Confidence (statement 5,6,7)}

The result found that $54.7 \%$ of the participants thought their confidence in English proficiency in writing improved. This was support by Kabilan and Abidin (2010) [74] that students' confidence in Malaysia was increased through English learning via Facebook. Moreover, Rahmah, Utami, Sholihatul, Maryati and Widia (2019) [91] found that writing class on Facebook boosted students' confidence and their engagement in class. In terms of reading English materials, 57.9\% of agree feedback was revealed. Similarly, for English communication skills, $50.3 \%$ of participants believed their confidence was leveled up. This may occur as students could talk to friends in English without worrying about language forms indeed. This was in vein with O'Hanlon (2007) [92] when students could speak English without embarrassment when they were allowed to take SNSs for learning collaboration.

\section{Motivation (statements 8,9, 10, 11,12)}

Table 6 revealed that $57.5 \%$ of the students agreed that Facebook could boost their motivation to communicate in English. This was in line with Puimom (2020) [22] when Thai Students' English speaking skill levels were increased than expected by uploading English clips on Facebook. Likewise, $63.5 \%$ of the study participants also asserted that Facebook enhanced their motivation to read in English. As for motivation in writing, 54.5\% of students concurred that Facebook was able to motivate them to do so. According to Blattner \& Fiori (2009) [52], Gamble\& Wilkins (2014) [75], Mazman \& Usluel (2010) [60]), it was believed that Facebook was a page that could motivate students in language learning. Based on the finding of the previous studies such as Nasser and Majid (2011) [93], Nazifah, Shafiq, Farhinaa, Othman (2012) [94], and Mok (2012) [95], this occurred due to SNSs as a supporting environment that leaded students enjoyed their language learning. As a result, students were willing to engage in activities. Furthermore, the finding was also similar to the study of Mas (2016) [96] who found that Indonesia students were motivated to acquire English or even attend class frequently thanks to using media in English speaking course.

\section{Attitude (Statement 13,14,15,16)}

In this regard of students' attitude, the findings were found to be similar to the previous studies in that perceived ease of use had the strongest significant influence on attitude towards use (Park, 2009 [67], Chang, Yan, \& Tseng, 2012 [68];). The second point for discussion was about students having a positive attitude toward using Facebook for doing the activities.
The result was similar to prior studies which also found positive attitude toward social media as a learning tool (Lewis, 2010 [97]; Lewis \& Nichols, 2016 [98]; Tashir, Al-Dheleai, Harun, Shukor, 2011 [99]). Moreover, this finding was supported by the studies ( Thao \& Dieu, 2020 [26]; Kabilan, Ahmad, \& Abidin, 2010 [74]; Eren, 2012) [100]) in that, students believed that Facebook could be a useful channel to trigger their attitude toward English learning demands positively.

To summarize, it could be believed there among a range of solutions to enhance language performance and competence in the SNSs- integrated learning, Facebook could be a pre-eminent medium of ELT to enrich Vietnamese students' language skills, learning attitudes, motivations and confidence.

\section{CONCLUSION, IMPLICATIONS, LIMITATIONS AND RECOMMENDATIONS}

\section{Conclusion}

Three issues are reflecting Vietnamese attitudes towards the use of Facebook applications for ELT that were addressed and advocated in the current study. More specifically, the first one is students' perceptions of the general ease of using Facebook, especially the Educational Use. Hence, Facebook - based ELT could be a proper choice to cultivate students' interests in the learning process. The second is students' attitudes toward the Usefulness of Facebook for engaging in specific activities for language learning. The study found that Interpersonal Communication was one of the prime purposes of using Facebook to learn English. This enables to advocate that Facebook is a useful communication tool for both students and instructors in education besides face-to-face communication in previous times. The final one from the study reconfirmed that English- major students in Vietnam were aware of the way how they should use Facebook to engage the entire development of learning language besides socializing for non-academic purposes. The study also found four aspects that Facebook impacted to facilitate English learning in Vietnam, encompassing students' attitudes, language skills, motivations, and confidence in which attitudes played the role more remarkable. Obviously, students' attitudes were changed in a better way. Learning a second or foreign language is a long-term process in which many linguistic and non-linguistic elements affect the whole process. Attitude is a non-linguistic factor that contributes to the language performance and competence in second language acquisition (Gardner, 1985 [101]; Gardner, 2000 [102]; Masgoret \& Gardner (2003) [103]. Hence, the study's findings may enable English teachers and learners to thoroughly consider the SNSs integration and direct presence of Facebook among existing methodologies and approaches in the digital years. 


\section{Implications}

The current offers a few implications towards the theories underpinning it. Firstly, the findings strongly suggest teachers and students can consider Facebook thoroughly as an online and offline classroom to build up language materials such as pictures and videos so that it assists listening and reading skills. Facebook could be a friendly official page for all stakeholders to keep connected on and off-campus management for school managers. For those who are policymakers in ELT, Facebook -based language approach could be promising possibilities for ELT that could help to increase students' learning outcomes and should be considered as a formal tool in ELT when people live in the exponential years in which ICTs and SNSs seem to be advanced endlessly.

\section{Limitations and Recommendations}

One of the first limitations of this study is that it mainly focused on the advantages of SNSs or Facebook in ELT. In the literature, ICTs and SNSs are double-edged swords could involve both advantages and pitfalls for general users and for ELT stakeholders and ELT members. A suggestion for future intensive research is that they should also be conducted to point out whether the drawbacks of using Facebooks exist negatively has strong interference or not. Briefly, contrastive analysis papers could be carried out. It is expected that new research gaps and pathways could be examined so that ELT students and educators could engage the total process of learning and teaching English with ease.

Secondly, to be supported by Technology Acceptant Model (Davis, 1989) [66], and the Theory of Facebook Usage for Education (Mazma and Usluel,2010), the present study aimed to reflect the Vietnamese language students' attitudes on existing of Facebook in their learning. Additionally, Facebook has been claimed that it has owned a great market share compared with other local and foreign SNSs in Vietnam. Despite it in reality, the serious lack of work has been found in the Vietnam context. In consequence of it, the present research is expected to contribute to the serious dearth of it in Vietnam context relating to Facebook or other SNSs in ELT.

Equally importantly, the study focused on students' attitudes towards to SNSs. Though the findings are likely to serve the ELT research significantly, this could be on the surface. Future studies could explore whether the students' attitudes and actual learning performance in ELT are correlated by adopting the qualitative method.

On the other hand, this study was conducted in Hochiminh City where is the South region of Vietnam. Nothing has been done to compare such findings with other regions of Vietnam. Hence, cross cultural studies can be done throughout the comparison of other places to examine that whether Facebook - based language learning can be applied in the wider scales or not. Last but not least, not only examining the attitudes towards the use of Facebook among English - major participants but it is possible to compare the effects of genders, age groups, academic background levels, nonEnglish major students on the use of Facebook in ELT so that Facebook - based learning could be applied in a long-term or not. By doing so, all in all, more ethnographic research needs to be conducted.

\section{REFERENCES}

[1] A. R. Sánchez, V. Cortijo, U. Javed, Students' perceptions of Facebook for academic purposes. Computers and Education. 70 (2014) 138-149.

[2] A. Suryani, ICT in education: Its benefits, difficulties, and organizational development issues. Jurnal Social Humaniora (JSH). 3(1) (2010) 13-33.

[3] P. T. T., Nhu, T. C. Wah, L. K. Keong. Exploring teaching English using ICT in Vietnam: The lens of activity theory. International Journal of Modern Trends in Social Sciences. 1(3) (2018) 15-29.

[4] N. A. Razak, H.A. Jalil, S.E Krauss, N. A. Ahmad, Successful implementation of information and communication technology integration in Malaysian public schools: An activity systems analysis approach. Studies in Educational Evaluation. 58 (2018) 17-29.

[5] N. A. Razak, H.A. Jalil, I, Ismail, Challenges in ICT integration among Malaysian public primary education teachers: The roles of leaders and stakeholders. International Journal of Emerging Technologies in Learning (iJET). 14(24) (2019) 184-205.

[6] P. Moodiel, Creating support and teacher relationship. (2007).

[7] C. Davies, P. Birmingham, Using ICT to enhance the learning experience in the classroom. Education Libraries Journal. 45 (1) (2002) 17-19.

[8] L.A. Adonis,Technology in schools. The British Journal of Administrative Management. (2006) 14-15.

[9] M. Monteith, ICT: Teaching primaryliteracy with ICT. Buckingham: Open University Press. (2002).

[10] J. Clement, Most popular social networks worldwide as of October 2020, ranked by number of active users. (2020). Retrieved March 12, 2016, from https:/www.statista.com/statistics/272014/globalsocial-networks-ranked-by-number-of-users/

[11] B. A. Lafford, Toward an ecological CALL: Update to Garrett (1991). The modern language Journal. 93, (2009) 673-696.

[12] Kirschner, P. A., \& Karpinski,A. C. (2010). Facebook and academic performance. Computers in Human Behavior. 26(6), 1237-1245.

[13] R. Junco, Too much face and not enough books: The relationship between multiple indices of Facebook use and academic performance, Computers in Human Behaviour. 28, (2012) 187-198. 
[14] R. Junco, R. Student class standing, Facebook use, and academic performance, Journal of Applied Developmental Psychology. 36 (2015) 18-29.

[15] M. Nkhoma, H.P. Cong, B. Au, T. Lam, J. Richardson, R, Smith, J El-Den, Facebook as a tool for learning purposes: Analysis of the determinants leading to improved students' learning. Active Learning in Higher Education. 16(2) (2015) 87-101.

[16] O. Kitchakarn, How Students Perceived Social Media as a Learning Tool in Enhancing Their Language Learning Performance. Turkish Online Journal of Educational Technology-TOJET. 15(4) (2016) 53-60.

[17] A. Akhiar, A. A. Mydin, S. A. A. Kasuma, Students' perceptions And Attitudes Towards The Use Of Instagram In English Language Writing. Malaysian Journal of Learning and Instruction. (2017) 47-72.

[18] S. Abrahim, B.A. Mir, H. Suhara, H., M. Sato, Exploring Academic use of online social networking sites (SNS) for language learning: Japanese students' perceptions and attitudes towards Facebook. J Inform Tech Softw Eng, 8(223): 2 (2018).

[19] S.A.K. Adi, L.T.D. Ai, ESL Reading Activities on Facebook among Malaysian University Students. Pertanika Journal of Social Sciences \& Humanities. 27(1) (2019).

[20] N. T. L Nguyen, Using ICT to foster collaborative writing for EFL university students in Vietnam. (2019).

[21] E. C. Avila, H.J. Cabrera Jr, The Use Of Facebook Group In Distance Learning During The Time Of Covid-19 Pandemic. PalArch's Journal of Archaeology of Egypt/Egyptology. 17(6) (2020). 1859-1871.

[22] S. Puimom, Enhancing Students' Motivation: Speaking Challenging Clips via Facebook. International Journal of Scientific and Research Publications. 10(7), ISSN 2250-3153 (2020).

[23] B. Siddig, Social Media in Teaching of Languages. International Journal of Emerging Technologies in Learning (iJET). 15(12) (2020) 72-80.

[24] Wongsa, M., \& Son, J. B. (2020). Enhancing Thai secondary school students' English speaking skills, attitudes and motivation with drama-based activities and Facebook. Innovation in Language Learning and Teaching, 1-12.

[25] T. Đạt, "Mạng xã hội Việt Nam đang ở đâu so với Facebook, Google?". Retrieved in November 24,2020, from https://vietnamnet.vn/vn/cong-nghe/ungdung/mang-xa-hoi-viet-nam-chung-ta-dang-o-dau-sovoi-facebook-google-688437.html

[26] T.Q. Thao, M.N.X. Dieu, Attitudes towards Facebook-based activities for English language learning among non-English majors. The 8th Open Tesol International Conference Proceedings. (2020) 558-576.
[27] N. P. Tuân, N.T. Tư, The Impact of Online Social Networking on Students' Study (VNU Unviversity of Economics and Business). VNU Journal of Science: Education Research. 29(1) (2013).

[28] P. Tran, Training learners to use Quizlet vocabulary activities on mobile phones in Vietnam with Facebook. JALT CALL Journal. 12(1), (2016) 4356.

[29] H. R. Van, T. La, Teachers' use of Facebook motivating Vietnamese students to improve their English language learning. In Mobile learning in higher education in the Asia-Pacific region. (2017) 359-375. Springer, Singapore.

[30] T. T. Q. Nhi, X.L. Mai, High School Students' Perceptions of the Use of facebook-based e-portfolios in EFL writing: a Case in the Mekong delta, Vietnam. European Journal of Education Studies. (2018).

[31] T.V. Le, Social media in learning English in Vietnam. (2018)

[32] H. Ngo (2018). The use of storytelling in online foreign language learning: a case study of a basic English grammar course provided to Vietnamese adult e-learners.

[33] D. T. T. Huong, B.T. Oanh, P.T.K. Oanh, L.K Luong, Using Facebook in Blended Learning in Vietnamese Undergraduate Students. In Journal of Physics: Conference Series (Vol. 1340, No. 1, p. 012008) (2019). IOP Publishing.

[34] T. T. T. Loan, Using Facebook as a tool to improve writing skills for tertiary students. Proceedings of ELT upgrades: a focus on methodology (2019), ISBN: 978604-67-1450-7 (2019).

[35] T. T. Vu, B. H. Bui, Blended Learning in University Writing Classes-Efficiency and Attitude. THAITESOL Journal, 33(2), (2020) 20-45.

[36] T. Nguyen, Undergraduate students' use of Facebook for educational purposes: Advantages, difficulties, and potential for connected learning. (2017)

[37] M. Prensky, Digital Natives, Digital Immigrants. On the Horizon. 9(5), (2001) 1-6.

[38] B. Woodcock, A. Middleton, A. Nortcliffe, Considering the Smartphone Learner: an investigation into student interest in the use of personal technology to enhance their learning. Student Engagement and Experience Journal. 1(1), (2012). 1-15.

[39] M. Samaha, N.S. Hawi, Relationships among smartphone addiction, stress, academic performance, and satisfaction with life. Computers in Human Behavior. 57 (2016) 321-325.

[40] A. D. Ahad, M. Anshari, Smartphone habits among youth: Uses and gratification theory. 
International Journal of Cyber Behavior, Psychology and Learning (IJCBPL). 7(1) (2017) 65-75.

[41] F. Hasmawati, Y. T. Samiha, A. Razzaq, A. M. Anshar, Understanding Nomophobia Among Digital Natives: Characteristics And Challenges. Journal of Critical Reviews. 7(13) (2020) 122-131.

[42] H, Omar, M.A. Embi, M Yunus, ESL learners' interaction in an online discussion via Facebook, Asian Social Science. 8(11), (2012) 67-74. doi:10.5539/ass.v8n11p67.

[43] G. Kessler, P. Hubbard, Language teacher education and technology. The handbook of technology and second language teaching and learning. (2017) 278-292.

[44] N. S. Ping, M. Maniam, The effectiveness of Facebook group discussions on writing performance: a study in Matriculation College. International Journal of Evaluation and Research in Education. 4 (1), (2015) 30-37.

[45] L. A. Shafie, A. Yaacob, P.K. Singh. Facebook activities and the investment of L2 learners. English Language Teaching. 9(8) (2016) 53-61.

[46] Z. Sun, C.H. Lin, J. You, H.J. Shen, Qi, S.,L. Luo, Improving the English-speaking skills of young learners through mobile social networking. Computer assisted language learning. 30(3-4), (2017) 304-324.

[47] S. Karim, H. He, G. A. Mallah. A.A. Laghar, H. Madiha, R.S.A. Larik, R. S. A. The Impact of Using Facebook on the Academic Performance of University Students. In International Conference on Artificial Intelligence and Security. Springer, Cham. (2019) 405418.

[48] Ahmed, M. I., Mustaffa, C. S., \& Rani, N. S. A.). Responding to covid-19 via online learning: the relationship between facebook intensity, community factors with social capital and academic performance. Palarch's Journal of Archaeology of Egypt/Egyptology. 17(6), (2020) 779-806.

[49] Inpeng, S., \& Nomnian, S. (2020). The use of Facebook in a TEFL program based on the TPACK framework. LEARN Journal: Language Education and Acquisition Research Network. 13(2) (2020) 369-393.

[50] M. Ganapathy, M. K. Kabilan, S. Meenakshisundram, English Language Teachers' Practices of Online Professional Development using Facebook. Pertanika Journal of Social Sciences \& Humanities. 28(1) (2020).

[51] S. Aydin, A review of research on Facebook as an educational environment. Educational Technology research and development. 60(6), (2012) 1093-1106.

[52] G. Blattner, M. Fiori, Facebook in the language classroom: Promises and possibilities. International
Journal of Instructional Technology and Distance Learning. 6(1), (2009) 17-28.

[53] S. Alnujaidi, Social Network Sites Effectiveness from EFL Students' Viewpoints. English Language Teaching. 10(1) (2017) 39-49.

[54] A.S. Martynova, Y.N Poddubnaya, I.E. Ostrovskaya, D.V.E. Zdor, \& Lomonosova, E. I. (2020). Social networks as an innovative resource for teaching specialty english to agricultural universities students. PalArch's Journal of Archaeology of Egypt/Egyptology. 17(7), 191-196.

[55] A. Kumar, H. Syed, Facebook as a Language Learning Environment: A Descriptive Study on ESL Learners' Perceptions. University of Chitral Journal of Linguistics \& Literature. 2(1) (2020) 68-81.

[56] S. Sumardi, M. Muamaroh, Edmodo impacts: Mediating digital class and assessment in english language teaching. Jurnal Cakrawala Pendidikan. 39(2) (2020) 319-331.

[57] S. Ketabi, \& S. Kavoshian, Innovative technology in English language teaching: the utility of mobile social network sites to improve teacher education. Teaching English Language. 11(1) (2017) 39-67.

[58] J. P. Guikema, M.R. Menke, Preparing future foreign language teachers: The role of digital literacies. Digital literacies in foreign and second language education. 12 (2014) 265-287.

[59] J. Clement. Leading countries based on Facebook audience size as of October 2020. Retrieved March 12, 2016,from

https://www.statista.com/statistics/268136/top-15countries-based-on-number-of-facebook-users/

[60] S. G. Mazman, Y. K. Usluel, Modeling educational usage of Facebook. Computers \& Education. 55(2) (2010) 444-453.

[61] W. Nasri, L. Charfeddine, An Exploration of Facebook.com Adoption in Tunisia Using Technology Acceptance Model (TAM) and Theory of Reasoned Action (TRA). (2012) 948-968.

[62] R. Da Rocha, P. Conradie, A. Lombard, Learner Perceptions on the use of Social Networking Services in Education: A Case Study. ICEL-Hosted by The Federico Santa María Technical University Valparaiso Chile. (2014) 241.

[63] S. Jin, Using Facebook to promote Korean EFL learners' intercultural competence. Language Learning \& Technology. 19(3), (2015). 38-51.

[64] D. Manasijević, D. Živković, S Arsić, I. Milošević, Exploring students' purposes of usage and educational usage of Facebook. Computers in Human Behavior. 60 (2016) 441-450. 
[65] B. Shefketi, M. Hamiti, Challenges of Facebook Integration in High Education. SEEU Review. 14(1), (2019) 207-225.

[66] F.D. Davis, "Perceived usefulness, perceived ease of use, and user acceptance of information technology", MIS Quarterly. 13(3) (1989) 319-400.

[67] S. Park, An analysis of the technology acceptance model in understanding university students' behavioural intention to use e-Learning. Education Technology \& Society. 12(3) (2009) 150-162.

[68] C. Chang, C. Yan, J. Tseng, Perceived convenience in an extended technology acceptance model: Mobile technology and English learning for college students. Australasian Journal of Educational

Technology. 28 (5) (2012) 809-826.

[69] A. Adwan, A. Adwan, A, J. Smedley, Exploring students' acceptance of e- learning using technology acceptance model in Jordanian Universities. International Journal of Education and Development using Information and Communication Technology. 9(2) (2013) 4-18.

[70] Shroff, R. H., Deneen, C. C. \& Eugenia, M. W. Ng (2011). Analysis of the technology acceptance model in examining students' behavioural intention to use an eportfolio system. Australasian Journal of Educational Technology. 27(4), 600- 618.

[71] V. Teeroovengadum, N. Heeraman, B. Jugurnath, Examining the antecedents of ICT adoption in education using an extended technology acceptance model (TAM). International Journal of Education and Development Using ICT. 13(3 (2017).

[72] R. Cakır, E. Solak, Attitude of Turkish EFL learners towards e-learning through tam Model. Procedia-Social and Behavioral Sciences. 176 (2015) 596-601.

[73] M.C. Lee, Explaining and predicting users' continuance intention toward e-learning: An extension of the expectation-confirmation model. Computers \& Education. 54(2) (2010) 506-516.

[74] M. K. Kabilan, N. Ahmad, M. J. Z. Abidin, Facebook: An online environment for learning of English in institutions of higher education?. The Internet and higher education. 13(4), (2010) 179-187.

[75] C. Gamble, M. Wilkins, Student Attitudes and Perceptions of Using Facebook for Language Learning. Dimension. (2014) 49, 72.

[76] J. Mazer, R. Murphy, C. Simonds, I'll see you on 'Facebook': The effects of computer-mediated teacher self-disclosure on student motivation, affective learning, and classroom climate. Communication Education. 56(1) (2007) 1-17.
[77] R. L. Thompson, C. A. Higgins, J.M. Howell, Personal computing: toward a conceptual model of utilization. MIS quarterly. (1991) 125-143.

[78] E.M. Rogers, Diffusion of innovations (5th ed.) New York: Free Press. (2003).

[79] P. Ractham, D. Firpo, Using social networking technology to enhance learning in higher education: A case study using Facebook. In 2011 44th Hawaii International Conference on System Sciences. (2011) (1-10). IEEE.

[80] L. Karimi, T.B.T. Ahmad, R. Khodabandelou, Sense of community and English perceived learning in a social networking site: A study of Facebook. International Journal of e-Education, e-Business, $e$ Management and e-Learning. 3(3), (2013) 224-228.

[81] E. Akbari, S. Eghtesad, R.J Simons, R. J. Students' attitudes towards the use of

social networks for learning the English language. (2012).

[82] H. Arendt, I. Matic, L. Zhu, Qualitative analysis of academic group and

discussion forum on Facebook. Unpublished manuscript. (2012).

[83] P. T. K, Thao, EFL Vietnamese students towards language learning autonomy. In UICELL Conference Proceeding. 2 (2018) 12-28.

[84] Bachate, A. K. "Teaching of Communication Skills Using Multimedia and Language Laboratory." Journal of Soft Skills 10 (3) 2016.

[85] S. Aydin. Foreign language learners' interactions with their teachers on Facebook. System, 42, (2014) 155-163.

[86] Rodliyah, R. S. (2016). [os] using a Facebook closed group to Journal. 27(1), 82-100.

[87] A. H. A. Majid, S. H. Stapa, Y. C. Keong, Blended Scaffolding Strategies through Facebook for learning and improving the writing process and writing performance. E-Bangi. 12(4) (2015).

[88] F. McCALL, Using microblogs on Facebook to develop students' academic reading and writing skills. University of Sydney Papers in TESOL, 12 (2017).

[89] A. B. Nadzrah, P. Mickan, Students' experiences in computer-based English language classroom. In Proceedings of the 2003 ASIA CALL Conference. Gyeongju University, South Korea: ASIACALL.

[90] P. Gannon-Leary, E. Fontainha, E. Communities of practice and virtual learning

communities: Benefits, barriers and success factors. eLearning Papers. 5 (2007) 1-14. 
[91] F. Rahmah, D. Utami, H. D Holihatul,S. Maryati Salmiah, and Widia Fransiska, "Using Facebook in EFL Writing Class: Its Effectiveness from Students' Perspective" in The Second Annual International Conference on Language and Literature, KnE Social Sciences. (2019) 634-645.

[92] C.O'Hanlon, If You Can't Beat'em, Join'em: Educators Who Recognize How Much Social Networking Engages and Informs Kids Are Creating Their Own Sites as Learning Tools that Foster Collaboration among Students, Teachers, and Parents. THE Journal (Technological Horizons In Education). 34(8) (2007) 39-44.

[93] O. Nasser, V. Majid. Motivation, Attitude, and Language Learning. Procedia- Social and Behavioral Science. 29, (2011) 994-1000.

[94] H. Nazifah, H. Shafiq, O. Farhinaa, K. Othman, Enhancing Students' Motivation by Providing Feedback Writing: The Case of International Students from Thailand. International Journal of Social Science and Humanity. 2 (6) (2012).

[95] J. C. H. Mok, Facebook and learning: Students' perspectives on a course. Journal of the NUS Teaching Academy. 2(3), (2012)131-143.

[96] D. I. Mas, Students' Motivation in Speaking English. Journal of English Educators Society. 1,

(2016) 31-48.

[97] B. K. Lewis, Social media and strategic communications: Attitudes and perceptions among college students. Public Relations Journal. 4 (3) (2010).

[98] B. K. Lewis, C. Nichols. Media and strategic communication: A three-year study of attitudes and perceptions about social media among college students. Public Relations Journal. 10(1), (2016) Social 1-23.

[99] Z. Tashir, Y.M.H. Al-Dheleai, J. Harun,N.A. .Shukor, Student's Perception towards the Use of Social Networking as an eLearning Platform. In Proceedings of the 10th WSEAS International Conference on Education and Educational Technology. 2011.

[100] Ö. Eren, Students' attitudes towards using social networking in foreign language classes: A Facebook example. International Journal of Business and Social Science. 3(20) 2012.

[101] R.C. Gardner, Social psychology and second language learning: The role of attitudes and motivation. London: Edward Arnold. 1985.

[102] R.C. Gardner, Correlation, causation, motivation and second language acquisition. Canadian Psychology. 41, (2000) 1-24.

[103] A. M. Masgoret, R.C. Gardner, Attitudes, motivation, and second language learning: A meta- analysis of studies conducted by Gardner and associates. Language learning, 53(S1), (2003) 167210.

[105] S. A. A. Kasuma, D. Wray, An informal Facebook group for English language interaction: A study of Malaysian university students' perspectives, experiences and behaviours. International Conference on Education and e-Learning (EeL). Proceedings: (2015). 1-10.

[106] S.H.F. Chen, How SNS Mediates EFL Adolescent Learners in Language Learning - From Learners' Perspectives. International Journal of Social Science and Humanity. 6(1) (2016) 19-25. http://dx.doi.org/10.7763/IJSSH.2016.V6.611 